\title{
Teaching Practices that Hinder the Deep Approaches to Learning of Twinning Programme Students in Malaysia: A Qualitative Perspective
}

\author{
Pauline Goh Swee-Choo \\ Universiti Pendidikan Sultan Idris, Malaysia \\ goh.sweechoo@yahoo.com
}

\begin{abstract}
This article reports on a qualitative study of students undertaking tertiary education under the twinning programme mode. The literature focuses on the importance of students adopting deep approaches to learning which leads to high quality outcomes. Findings provide descriptions of teaching practices that hindered deep approaches to learning including superficial teaching lacking in imagination and enthusiasm, slow or non-existent feedback of student work, and the issues of teacher bias and favouritism. Suggestions are made for teaching practices in twinning programmes.
\end{abstract}

Keywords: Approaches to learning; learning environment; twinning programmes and modes; content knowledge; pedagogical content knowledge.

An unprecedented expansion of higher education has been taking place in Malaysia since the early 1980s. In most cases, this expansion has occurred through campus-based public universities following their home-grown degree programmes. The expansion was further compounded by the Malaysian Education Act of 1996 which placed emphasis on higher education. Higher education was directed at increasing enrolment at the degree levels (Government of Malaysia, 1996, 2001) and efforts were put into place to increase the number of public universities. However, with the increasing demand for higher education, it also became a strain for the government to meet the demand and to sustain in both economic and financial terms (Lee, 1999; Zakaria, 2000).

To complement the aspiration for more Malaysians to pursue tertiary education, the government has allowed what is known as the 'twinning programme.' Twinning programmes allow students to spend different undergraduate study periods in the home country and in overseas universities (usually western universities, of which Australian and British universities are well represented). Alternatively, the students can complete the foreign degree locally at their home institutions. Generally, in twinning programmes, the students use a similar curriculum, syllabus and satisfy the entry requirements of the foreign twinning partners.

Since there are relatively few students of higher education around the world undertaking the twinning mode, it is not particularly surprising that there is a lack of research literature on this. Research concerned with twinning programmes are generally subsumed or briefly mentioned under 
literature on higher education from campus-based home-grown degree programmes. However, a particular focus of research interest in both forms of degree programmes has been the approaches to learning that are exhibited by students in their relevant programmes. Much research has contributed to the understanding of how students approach their learning from campus-based home grown degree programmes (see Abd Rashid, 2002; Biggs, 2001; Burnett \& Dart, 2000; Case, 2000; Cowman, 1998; Kember, 2000; Watkins \& Mboya, 1997). There are, in contrast, fewer studies carried out on twinning programmes and these are often much less widely available (e.g. Goh, 2006; Lee, 1999).

Students in twinning mode are introduced to a curriculum that is derived from aims of higher education of the 'importer.' They are expected to learn challenging materials and be capable of independent thought. In addition, students in twinning mode work in a learning environment that is both unique and complex, as they are required to function within a context which advocates ideals of their partner overseas universities but which still remain within the boundaries and constraints of a local private institution. They are sometimes required to adjust between being taught by local and overseas deliverers. Yet, little attention has been given to this particular group of students and to their learning within the 'twinning' arena.

The present report is seen as an important step in seeking a better understanding of twinning programme students' perceptions of their approaches to learning and their own experiences of learning as they perform various tasks and attempt to understand the learning materials.

\section{BACKGROUND LITERATURE}

The concept of approaches to learning has always been important in focusing the attention on how students relate to and operate a learning task. An approach to learning is a description of a relationship between a student and a learning task
- of how the student intends to undertake the task (Martön \& Säljö, 1976). The surface approach to learning is seen as an approach driven by extrinsic motivation, and extrinsic to the real purpose of the task (Biggs, 2001). The intention is to meet requirements with as little effort and time as possible. One of the methods is to memorise material. Rote learning does not automatically mean that a student is adopting a surface approach, because rote learning can be acceptable when verbatim recall is needed. It becomes a surface approach if the student rote learns answers to previous examination questions. According to Ramsden (1992, p.45), surface approaches "are uniformly disastrous for learning ... they may permit students to imitate authentic learning and to bamboozle their teachers into thinking that they have learned ... the snag is that you may survive the exam but you will almost certainly forget everything you memorized for it after a few days." An outcome of surface learning is that the underlying meaning tends to become lost or fails to be integrated into the learner's knowledge base; there is no analysis of the learned material. Biggs $(1987,2001)$ has suggested that students who continue to use a surface approach not only have poor performance outcomes but also tend to terminate their higher education after a first degree.

By contrast, the deep approach is based on an intention to engage in the task meaningfully (Biggs, 2001). There is an attempt to understand what is learned and to relate it to both previous knowledge and previous experience. The aim of deep learning is to engage in a task with learning processes that are appropriate to completing it satisfactorily (Biggs, 2001). Martön and Säljö (1984, p. 46) stated "We are not arguing that the deep/holistic approach is always "best:" only that it is the best, indeed the only, way to understand learning materials." Resultant outcomes are high quality learning, including the development of analytic skills (Biggs, 2001; Gordon, Simpson \& Debus, 2001). As Ramsden (1992, p.61) stated:

Deep approaches are connected with qualitatively superior outcomes which we 
associate with understanding a subject: the making of an argument, the novel application of a concept, an elegant solution to a design problem, an interplay between basic science knowledge and professional application, mastery of relevant detail, relating evidence correctly to conclusions.

In this framework, it is hoped that twinning programme students adopt deep approaches to learning. Ideally, all twinning programme students should go beyond the rote memorization skills that characterize surface approaches and outcomes, and develop deeper approaches in areas of research, analysis, problem solving, communication and writing skills.

However, is this necessarily so? This study contributes to the limited literature of twinning programmes by exploring the problems that students experience in completing their degree and advancing their own knowledge under the twinning mode. The study is not intended to diagnose the success or failure of a twinning programme in promoting deep approaches of learning, rather, the intention is to provide the course deliverers, administrators, and educators of twinning programme with a general overview of student experiences in the twinning mode.

\section{METHOD}

In order to penetrate the 'real-world' issues of students from twinning programmes, detailed and rich qualitative data were required. Phenomenological assumption states that students are inextricably related to the contexts in which they live and work (Martön, 1981). Rationally then, interviews provide the best means into how students "experience, conceptualise, perceive and understand various aspects of, and phenomena in, the world around them" (Martön, 1986, p.31).

It was considered important that students were mature enough to make valid and careful judgements about their learning in the twinning programme to ensure careful responses to the interviews. In addition, it was necessary that students were established in their place of learning and had formed certain learning habits. Therefore, only second and third year students who volunteered were selected. A total of 52 students were interviewed. These students came from three different degree programmes business, computer science and engineering. There were 25 males and 27 females of which seven were Malays, 33 were Chinese, 10 were Indians and three from indigenous races (of Iban and Kadazan descent).

During the interviews, the students were asked questions about teaching strategies and practices used by their lecturers, influential people who facilitated their learning or helped to optimise their learning outcomes (necessitating retrospective accounts), exploration of the approaches to learning used in learning, and feelings and perceptions about their learning environment. On the average, each interview lasted approximately one hour. Verbatim transcription was undertaken, usually fairly soon after the interview had taken place. A method of 'free' and 'open' coding was employed in order to classify responses into meaningful themes and categories. It was followed by a more careful 'interactive reading and re-reading' to establish similarities and differences in the data (Entwistle $\&$ Martön, 1994). At all times, the themes and categories from the interview data were integrated with relevant literature pertaining to 'learning approaches' (Biggs, 1987, 2001; Ramsden, 1992).

To provide realistic insights, data from the interviews were not edited, but rather presented in verbatim form. However, interviews that were spoken in Bahasa Melayu (Malay language) or the Chinese Hokkien dialect (dialect from the Fujian province in China) were translated as closely as possible so that the original meanings were not lost. As much as possible, students' responses were presented as they were spoken, to reflect a realistic picture of students' learning and working within the twinning programme environment. 


\section{RESULTS AND FINDINGS: TEACHING PRACTICES THAT HINDER DEEP APPROACHES TO LEARNING}

Ideally, every educator and administrator of twinning programmes would like their students to acquire deeper levels of understanding of their course in learning environments that promoted deep approaches to learning. However, the findings of this study indicated that students encounter a number of negative teaching practices that could defeat these aims if not addressed. The lack of both content knowledge and pedagogical content knowledge appears to be a negative factor. Students perceive their lecturers to be ineffective in helping them make sense of the subject matter. Also, students reported lecturers who failed to exhibit professional behaviours and professional demeanour required of the profession. Several students were vehement about issues of teacher bias and favouritism.

\section{LACK OF CONTENT KNOWLEDGE AND PEDAGOGICAL CONTENT KNOWLEDGE}

Lecturers who did not have a deep understanding of their subject matter (lack of content knowledge) encountered difficulties in leading and assisting their students in understanding concepts and helping them relate prior learnt knowledge to new ideas or to attend to misconceptions in knowledge. Similarly, there were difficulties too when lecturers did not possess the necessary skills to enable ideas to be communicated to their students or how to represent or reformulate their subjects to make it understandable to their students (lack of pedagogical content knowledge). Lecturers' lack of content knowledge or pedagogical content knowledge in this study had manifested itself in the absence of expertise in the subject matter, unimaginative teaching, inability to relate concept to real situation, and the lack of useful and timely feedback.

\section{Absence of expertise in the subject}

There are times when although the subject is interesting, the lecturer made me demotivated or dislike the subject. I feel sad about it. (Male, Malay, Computer Science)

When asked to give examples of what was meant when a lecturer 'de-motivated,' the response was the inability of the lecturer to respond to questions related to the subject which shattered the confidence the student had in the lecturer.

It is bad when the lecturer purposefully forget what we ask because he don't know how to answer. With this kind of lecturer, we will not get the latest knowledge. (Male, Malay, Computer Science)

\section{Unimaginative teaching}

Unimaginative teaching and superficial skimming of the learning materials by lecturers compounded students' use of shallow memorisation of information.

[Translated from the Hokkien dialect] I remember this lecturer, she gives us the notes, then she will use the projector on the board and she will read the notes word for word ... If she can explain what the notes mean would be better, just read, you know, everyone of us can read right? She requires the answer to be exactly what she gives us from her notes. If we use another words, like use our own words to explain, it is not acceptable. (Female, Chinese, Computer Science)

The following passages from two students were fairly typical of the other students interviewed when discussing the ways lecturers were responsible for their use of memorisation, partly because of the lecturers' inability to explain clearly and the large amount of unrelated notes given.

Take for an example a lecturer who says this 'this won't come out for exams, no need to worry', they straight away tell me that he 
don't know the subject himself, that is why those statements were made. So how does he expect us to be good in the subject? When we ask a question, he will link it to something totally irrelevant and don't know how to explain, and talk nonsense even to the point of talking about toilets. He is good at talking, but we never get an answer. I will listen for an hour only. I have no problem with pretending to listen, ears open but brains somewhere else. (Male, Chinese, Engineering)

He is like using his own materials, the materials are a little related to the subject but not totally. I will get piles and piles of notes, and when exams come, there is no time to study, what else to do - so take a few pages of notes that are important and memorise. (Male, Indian, Business)

\section{Inability to relate concepts to real situation}

Another problem found was not only lecturers' inability to explain things but also the inability to relate it to the real working environment.

The lecturer is too serious, no humour, they could ask us for opinions and give real live examples, rather than they just yak, yak, yak, yak. (Male, Chinese, Business)

The lecturer's ability to perform well was not necessarily seen as effective teaching and students were able to discern between lecturers who advanced their learning with those who had 'entertained' them.

... students liked her because she is very pretty, she walks up and down, makes jokes, talks well, but she cannot teach. She delivers from books. During tutorials, she will read out the answers without the explanations. (Male, Chinese, Business)

\section{Lack of useful and timely feedback}

Giving quality feedback on students' work was perceived to be important, but as the comments show, it appeared to be lacking. Several students expressed frustration at being left in the dark about their effort, and felt it was 'time-wasting' to do a piece of work and not know if it was right or wrong or even meaningful. They commented on the importance of timely feedback so that they would not make the same mistakes.

He does not give any feedback. He will keep asking for opinions, but in the end, what is the correct one, all students want to know right? (Female, Chinese, Computer Science)

I think when we finish the assignments and we pass up, after they [..referring to lecturers..] have checked, they should give it back to us and give us comments on where we go wrong, and how we can improve ourselves. (Female, Chinese, Computer Science)

The following comments reflected the frustration students felt when feedback was not forthcoming from their lecturers.

I am not asking for too much, but if like the lecturer can tell me why I did something wrong and give me feedback, I would probably work harder. (Male, Chinese, Business)

I would prefer feedback to be given so that I am able to get some idea of where and why I went wrong. But sometimes there are no feedbacks at all, maybe because the lecturer lacks the experience to even know what to say and comment, maybe also the lecturer dares not give feedback in case we students question back. (Male, Chinese, Engineering)

We do not get feedback at all, we only know our marks. We do not get things like how to improve. ... Sometimes we feel like it is time wasting to do assignments. (Male, Chinese, Computer Science)

\section{Lack of positive professional disposition}

Students recognized lecturers who did not exhibit positive professional behaviours in their 
classroom or during lectures. When this happened, students reported that it had a negative effect on their approaches and attitudes towards learning. Some of the commonly reported behaviours are unfair treatment, being biased and personal, and showing favouritism.

\section{Unfair treatment}

Students did not appreciate being picked on by their lecturers; they felt that at the level of higher education they should be equally respected.

Stop picking on us, be fair. They [..referring to the lecturers..] always purposely ask some of us to answer questions, especially if it is a tough question, then if we cannot answer then they will say - 'ah see never go for classes'. They embarrass us students. Maybe they think we can be afraid of them, but it gives the opposite reaction. (Female, Chinese, Business)

When the same student was asked to elaborate on what she meant by "opposite reaction," she explained:

If they [..the lecturers..] cannot respect us, why should I? They think we are afraid they will fail us and must 'bordek' [..colloquial for 'be extra nice to'..] them?

\section{Being biased and personal}

"Lowering" or having marks made lower was noted by several students who felt that lecturers were biased and being "personal" about situations. This view was expressed as:

He [..referring to the lecturer..] will blacklist the students who come late or those students who do not take part in class. He will blacklist from classroom up to private life. If we see him outside, he will not acknowledge those he blacklists; even if he has a good knowledge, his teaching approach is not friendly; his marking scheme is very low. No matter how much we struggle or put in effort, he will give low marks. We don't know what went wrong.... He should judge students from our standards. (Male, Indian, Business).

Some bad lecturers, they cannot take students' attitude, they easily snap and then become sarcastic, maybe they think we are still in secondary school ... We just laugh and we do not feel hurt at all ... Sometimes our marks are always lower than the others ... a bit biased. (Female, Indian, Business)

Another time, the lecturer doesn't want to entertain us, even though he knows we did quite well. ... I don't know why, but our group always get lower marks. (Male, Chinese, Engineering)

They [.. referring to the lecturer ..] penalize those weaker students and those students who don't go for classes, that kind of things. Some lecturers are like that, they just discriminate. (Female, Chinese, Business)

Apparently, such situations served to demotivate:

No motivation in it, need to pass the degree, I just want to finish it. If it [...referring to the subject..] was not compulsory, I would not bother to take it. (Female, Indian, Business)

\section{Favouritism}

Other students, on the other hand, who had better rapport with their lecturers, were viewed as being especially favoured, and were given more help.

Lecturer must not take sides to certain students or pay more attention to one group of students. ... I think the group approached the lecturer so many times, they build this relationship. ... Those who don't ask much, or are quiet, are neglected. (Male, Chinese, Engineering)

Lecturers will notice the active or outstanding student in class, they will think this student is a good student, smart or intelligent. ... Lecturers will notice the students who approach them more, close to them. ... She/ he will remember you more. So when you 
asked, you will get more than other students, it is not fair to the other students. ... Normally, the lecturers will only look at students who are performing well. They do not really bother about the rest. Maybe they [..referring to students..] have problems why they do not do well, maybe they have problems with English, shy, or do not understand what you are teaching? (Male, Chinese, Business)

A few students felt neglected by their lecturers because they were more in control and more independent in their own learning. Students commented that their lecturers were aware that they would be immersed in more independent work when they transferred to overseas Western universities, and felt grateful that their lecturers were trying to expose them to the different kinds of learning cultures they might find overseas. Students found that their lecturers did not work as hard at explaining things and expected them to undertake research to find the answers to questions. Most students realised that they should be less dependent on their lecturers or tutors and to take control of the organisation of their own learning. However, a few felt that their lecturers were not doing it effectively, and tended to ignore those who adapted well to independent work over those who found it difficult. The reverse result may occur, where students might revert to old approaches because it was perceived that lecturers tended to neglect students once they were able to be more self-reliant in their work.

Miss [..name..] do encourage us to do independent work, she says that it is better we get used to doing it now because when we go overseas next year, lecturers there will not provide notes or hold our hands, but she is not doing it effectively though. Some of my friends and myself, we enjoy having the freedom to see how we can complete our work, and also how we can sometimes talk to her about what we want to do in our assignments.... She encourages us telling us we need to do this [..referring to being independent..] but at the same time, she overly attends to students and give free marks to those who complain about independent work. ... She pays attention to students who cannot do their work themselves and ignore those who are into independent work. Implementation is not effective. (Female, Indian, Business)

When asked how such situations would make them feel:

If we have lecturers like this, then we will not have the motivation to really study as we know she/he will not be asking us anything and we have 'let us not do it' attitude. (Female, Indian, Business)

Negative students' attitude and a general disappointment appeared to be prevalent when students encountered differential treatments from their lecturers. It appeared also to influence how they viewed their learning, which was reflected in passive and submissive behaviours.

Once a lecturer was very angry with a guy who did not do her tutorial questions and then she walked out of the class and ignored those who have done the tutorial questions, and he [..the student..] was nearly barred from the exams until he appealed. Because of this I do not dare do anything, ask her or contradict her, just do what she wants. (Female, Chinese, Computer Science)

I don't want to make him [...referring to her lecturer..] angry, he may mark us down. I feel sometimes he will disadvantage us, make our marks lower. (Female, Chinese, Computer Science)

\section{DISCUSSION}

This study identified the context specific problems that twinning mode students encountered in developing deeper understanding of their lessons. The perceived lack of subject expertise and the lack of the kinds of knowledge lecturers should 
have in order to be effective in the classroom or in lectures which manifested as lecturers being unenthusiastic and unimaginative in their teaching did not provide the stimulus for students' involvement and commitment to the lesson.

In addition, behaviours of lecturers such as being prejudiced, threatening and intimidating did little to provide the positive emotional and motivational conditions necessary for deep learning. Instead, such discouraging factors were found to be instrumental in students developing passive and submissive attitudes and adopting surface learning.

The use of irrelevant handouts and materials was also mentioned as contributing to students' confusion. The description of using a surface approach as a manifestation of lecturers' actions, well intentioned or otherwise, could arise from such circumstances and as a result, students who are deep approach learners could be forced to employ surface methods such as rote learning for the replication of notes. Students expressed the importance of timely and useful feedback as part of good teaching. Feedback was perceived as essential in helping them develop ideas and a lack of it was perceived to hinder their learning and was a discouraging factor.

The students commented that those students who seemed to be more articulate or who seemed to be more intelligent were able to capture and monopolise the lecturers' attention whereas those students who had a better grasp of doing work independently had less time available to them from their lecturers.

An interpretation of the data appeared to indicate that the manner by which students went about learning were linked to how their lecturers approached and conducted their teaching or disseminated the learning information. Students were able to recognize teaching practices that were barriers to their use of deep approaches to learning. Students were critical of teaching practices which were not constructive, non-committal, apathetic, showed favouritism, and did not cater to the needs of different students. The intrinsic interest in the learning experience in twinning programmes was affected by negative educators' behaviour and attitude (probably unintentional at times) towards the whole process of teaching and learning. Thus, an expedient surface approach to learning was adopted, with students discarding the rich learning experience espoused by education with the aim of merely obtaining a degree.

\section{IMPLICATIONS FOR TEACHING PRACTICE IN TWINNING PROGRAMMES}

The study has implications for educators in twinning programmes, and certain helpful suggestions are given:

1) One of the key findings is that appropriate teaching practices, supportive teacher attitudes, and the provision of positive learning environments are important factors in student learning. Lecturers must be aware that they can enhance student motivation, that they can improve their teaching approaches, that they can modify their attitudes and behaviours, and that these changes do affect student learning. Gow, Kember, and Sivan (1992) indicated that many higher education lecturers are unaware that their teaching practices produce effects quite different from those they intended. Horsburgh (1999), Smyth (2003), and MacLaren (2005) have noted that staff training programmes have shown to make an impact on how teachers view their teaching and their students' learning. Some form of professional development programmes can be initiated as a way to improve academics' teaching performance and for them to become aware of some of the potentially negative aspects of their teaching approaches. It can serve as a platform to share and align teaching practices between the local and partner institutions. However, professional development programmes must not be restricted to merely promoting desired changes, but academics must also understand that they should take responsibility for those negative elements which are barriers to optimal learning, and that these 
do require attitude and behaviour changes (Gow et al., 1992).

Professional development can take a few forms:

a) Adequate funding and time-out allowances can be arranged between twinning partners and local institutions to provide twinning programme lecturers with teaching attachments at partner universities.

b) Collaborate in action research projects to promote change through active participation, group work and group decision making. Implementation of new innovations can be mutually shared as a group with continuous assistance and advice.

2) Malaysian students who come from more traditional school systems where rote-learning and the expectation of being 'spoon-fed' are prevalent (see Mustafa, 2003; Ahmad, 2000; Nalliah \& Thiyagarajah, 1999) need academics to guide them in organising information or to be analytical in problem solving in their reading and studying. It is important to guide students towards adopting deep approaches to learning. For example, lectures can initially be sequenced and structured to explain important concepts and theories, followed by explanations that can show the relationship of what they are learning to real life situations. By showing students the reality of what they are learning, students will be able to reflect on the importance of what they are learning, thus stimulating their interest. In addition, students can explore new concepts and ideas learnt through group work discussion, through solving problems from authentic case studies and projects, and through appropriately planned practical laboratory sessions. Academics should be aware that test questions and problem solving activities should be made more challenging so that they require students to adopt deep approaches, thus helping them discard their habit of shallow memorising or a dependence on finding answers to past examination questions. Academics should also be aware that Malaysian students are reluctant to express their opinions openly or contradict their lecturers because of the respect they have for their elders. This does not necessarily mean that students are passive and lack the ability to think critically; rather academics can assist them by providing opportunities for them to argue or agree on issues and problems without fear or favour.

3) Academics should be aware of the needs and differences of the diverse student groups in their classes. Efforts should be made to discard teaching environments that are threatening and prejudiced and adopt those that are satisfying, rewarding, and non-discriminatory. Such efforts should include regarding students' views and opinions, giving students a chance to express themselves in their own way, avoiding preferential allocation of marks in tests or assignments, and by not spending excessive time with particular students or groups.

\section{CONCLUSION}

This article presented findings from an original qualitative study of Malaysian students' perceptions of learning and working within the twinning programme environment in Malaysia. Although deep understanding is the goal in twinning modes, deep understanding is impeded by educators' teaching approaches and disparaging attitudes and behaviours. It is important to note that teaching practices that hinder deep approaches to learning described here need to be addressed not only for the sake of current students, but also in the interest of a quality learning environment to facilitate deep level approaches to learning. It is hoped that this study can help twinning programme providers and their overseas partners to make improvements where needed so that future twinning programme students will find studying a rewarding experience and a study option worthy of consideration. 
The higher education requires much productive further study on students operating within the twinning programme. For example, are students learning in the twinning mode qualitatively different from students undertaking home-grown degree programmes in terms of their approaches to studying? Are there differences in approaches to learning of students and differences of perceptions between students who are studying in overseas partner universities undergoing the same programme? Would the effects of age, academic qualification, or socio-economic background upon students' approaches to learning be different in twinning programmes compared to those in campus-based home-grown degree programmes? After all, in the latter context, students are subject to restriction of entrance requirements (example, course availability, ethnic quota, and age)? Future studies on twinning programme education may be enriched and furthered by addressing these types of questions and by looking at it from both a qualitative and quantitative perspective.

\section{REFERENCES}

Abd Rashid, A.R. (2002). Dasar inovasi pendidikan dalam konteks agenda wawasan 2020. In S.Hussin (Ed), Inovasi dasar pendidikan perspektif sistem dan organisasi (pp.19-47). Kuala Lumpur: Penerbit Universiti Malaya.

Ahmad, K. (2000, November). Peranan pentaksiran dalam pembetukan masyarakat yang berfikir dan belajar. In proceedings of the International conference on teaching and learning (Vol.2, pp.468-475).

Biggs, J.B. (1987). Student approaches to learning and studying. Melbourne: Australian Council for Educational Research.

Biggs, J.B. (2001). Enhancing learning: a matter of style or approach? In R.J. Sternberg \& L.F. Zhang (Eds.), Perspectives on thinking, learning, and cognitive styles (pp.73-102). Mahwah, NJ: Lawrence Erlbaum Associates.

Burnett, P.C., \& Dart, B.C. (2000). The Study Process Questionnaire: a construct validation study. Assessment and evaluation in higher education, 25, 93-99.

Case, J.M. (2000). Students' perceptions of context, approaches to learning and metacognitive development in a second year chemical engineering course Unpublished doctoral disseration, Monash University, Australia.

Cowman, S. (1998). The approaches to learning of student nurses in the Republic of Ireland and Northern Ireland. Journal of Advanced Nursing, 28, 899-910.

Entwistle, N., \& Martön, F. (1994). Knowledge objects: understandings constituted through intensive academic study. British Journal of Educational Psychology, 64, 161-178.

Goh, P.S.C (2006). Assessing the approaches to learning of twinning programme students in Malaysia. Malaysian Journal of Learning \& Instruction, 3, 93-115.

Gordon, C., Simpson, T., \& Debus, R. (2001). Improving quality learning in a pre-service teacher education programme. Retrieved January 23, 2004 from http://www.aare.edu.au/ 01pap/gor01441.htm.

Government of Malaysia (1996). Seventh Malaysia Plan 1996-2000. Kuala Lumpur: Government Printers.

Government of Malaysia (2001). Eighth Malaysia Plan 2001-2005. Kuala Lumpur: Government Printers.

Gow, L., Kember, D., \& Sivan, A. (1992). Lecturers' view of their teaching practices: implications for staff development needs. Higher Education Research and Development, 11, 135-149.

Horsburgh, M. (1999). Quality monitoring in higher education: the impact on student learning. Quality in Higher Education, 5, 9-25.

Kember, D. (2000). Misconceptions about the learning approaches, motivation and study practices of Asian students. Higher Education, 40, 99-121.

Lee, M.N.N. (1999). Private higher education in Malaysia. Malaysia: School of Educational Studies, Universiti Sains Malaysia. 
MacLaren, I. (2005). New trends in academic staff development: reflective journals, teaching portfolios, accreditation and professional development. In G. O'Neill, S. Moore. \& B. McMullin (Eds), Emerging issues in the practice of university learning and teaching (pp.111-118). Dublin: AISHE 2005.

Martön, F. (1981). Phenomenography - describing conceptions of the world around us. Instructional Science, 10, 177-200.

Martön, F. (1986). Phenomenography - a research approach to investigating different understanding of reality. Journal of Thought, 21, 28-49.

Martön, F., \& Säljö, R. (1976). On a qualitative differences in learning: I - outcome and process. British Journal of Educational Psychology, 46, 4-11.

Martön, F., \& Säljö, R. (1984). Approaches to learning. In F. Marton, D. Hounsell, \& N. Entwistle (Eds.), The experience of learning (pp.36-55). Edinburgh: Scottish Academic Press.
Mustafa, M. (2003). School-based assessment to cover more subjects. Retrieved July 29, 2003 from http://www.studymalaysia.com/ cgibin/newspro/builtnews.pl?newsid $=1059183009$.

Nalliah M., \& Thiyagarajah, R. (1999). Malaysia: Review of educational events in 1998. Asia Pacific Journal of Education, 19, 95-102.

Ramsden, P. (1992). Learning to teach in higher education. London: Routledge.

Smyth, R. (2003). Concepts of change: enhancing the practice of academic staff development in higher education. International Journal for Academic Development, 8, 51-60.

Watkins, D., \& Mboya, M. (1997). Assessing the learning processes of black South African students. The Journal of Psychology, 131, 632-640.

Zakaria, A. (2000). Educational development and reformation in the Malaysian education system: challenges in the new millennium. Journal of Southeast Asian Education, 1, 113-133 